\title{
Impact of precipitation and runoff on ephemeral gully development in cultivated croplands
}

\author{
VLADIMIR KARIMOV, ALEKSEY SHESHUKOV \& PHILIP BARNES \\ Department of Biological and Agricultural Engineering, Kansas State University, 129 Seaton Hall, Manhattan, \\ Kansas 66506, USA \\ karimov@ksu.edu
}

\begin{abstract}
The goal of this study was to estimate the impacts of precipitation and runoff on ephemeral gully development. A field experiment was conducted during the summer of 2013 on an agricultural field near the city of McPherson in central Kansas, USA. Precipitation data were collected, and the gully headcut was measured every three to four weeks. The rainfall excess was calculated with the WEPP model, whereas headcut soil losses were estimated based on measurements. Headcut measurements showed that there was no gully development during rainfall events of short duration of high or low intensity. However, headcut propagation was clearly detected under saturated soil conditions for a three-day storm. This field study provides data to model the mechanics of ephemeral gully development. Further measurements of precipitation and gully morphology are needed for statistical analysis of gully erosion and the associated soil losses.
\end{abstract}

Key words ephemeral gullies; soil erosion; soil moisture; runoff

\section{INTRODUCTION}

Increasing global population has raised demand for higher productivity from agriculture. One of the issues that limit the productivity is soil loss due to wind and water erosion. Ephemeral gullies were reported to contribute to (in median) $40 \%$ of total soil loss due to water erosion (Poesen et al., 2003; Wilson et al., 2008; Taguas et al., 2012).

Many studies have theoretically evaluated soil erosion caused by ephemeral gullies. This research led to the development of soil erosion models, such as REGEM, EUROSEM and CREAMS (Alonso et al., 2002; Taguas et al., 2012; Morgan et al., 1998; Nachtergaele et al., 2001). Other studies have focused on ephemeral gully development by conducting field experiments (Thorne et al., 1984; Thomas and Welch, 1988; Casalí et al., 2009; Di Stefano and Ferro, 2011; Gong et al., 2011; Wells et al., 2013). This experimental approach mainly incorporates the use of photogrammetric scanning of the ephemeral gully area and precipitation measurement. However, Castillo et al. (2012) showed that the photogrammetric method of gully assessment was not very accurate and needs to be improved.

Several research attempts have been undertaken to investigate processes associated with propagation of concentrated flow channels including rills and ephemeral and classical gullies, but an effect of antecedent moisture content was often overlooked. For example, Stein et al. (1993) modelled rill advancement by conducting laboratory flume and field experiments, but did not consider the impact of antecedent moisture content on rill propagation rates. Robinson and Hanson (1996) reported no strong correlation between soil moisture content and gully propagation rates based on their flume experimentation. An experiment similar to Robinson and Hanson (1996) was conducted by Bennet et al. (2000) where moisture content was held at constant value. Soil water content was not included in simulations by Alonso et al. (2002). Capra et al. (2009) noticed an impact of three-day cumulative rainfall depth and the associated soil moisture conditions on ephemeral gully propagation. Wells et al. (2009) studied soil texture, tailwater height, and porewater pressure as factors important in gully development, and reported that experimental data show(ed) that the presence of a water table near, at, or above the soil surface greatly increases soil losses (Wells et al., 2009).

In addition to soil moisture, many other factors affect gully development, for example, rainfall amount and runoff, soil type and texture, topography, and land management (Valentin et al., 2005; Zhang et al., 2007; Capra et al., 2009; Wells et al., 2009). In this study, we focus our attention on soil moisture, precipitation and runoff by conducting a field experiment on a cultivated cropland. Rainfall, soil moisture content and change in gully shape were measured during the growing 
season and runoff fluxes were model simulated. Conclusions were made on the influence of soil moisture content and runoff fluxes on ephemeral gully development.

\section{MATERIAL AND METHODS}

\section{Site description}

The study was conducted at an experimental field site located in the Little Arkansas River watershed near the city of McPherson, central Kansas (Fig. 1). The field was in no-tillage for the last 7 years, and in a winter wheat-corn-sorghum crop rotation. The soil type is Crete silt loam soil with an average slope of $0.6 \%$. The field had two developed channels that transported runoff from two adjacent fields. The studied ephemeral gully was a tributary to one of these channels. A headcut and the drainage area of the ephemeral gully headcut of 1.2 ha are presented in Fig. 1.

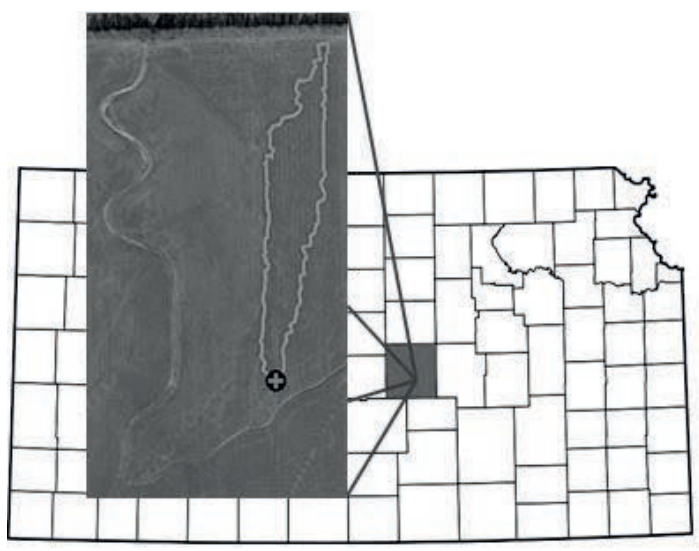

Fig. 1 The drainage area and headcut of the studied ephemeral gully in central Kansas.

\section{Measurement of precipitation and soil moisture content}

To measure precipitation depth and soil moisture content continuously, a weather station with data logger was installed (Fig. 2(a); Onset, 2013). A tipping bucket-type raingauge and eight volumetric soil moisture probes manufactured by Decagon Devices Inc. (Decagon, 2013) that measure the dielectric constant of porous media were connected to the data logger. The weather station was installed on a wooden post $2 \mathrm{~m}$ downslope of the headcut and $1 \mathrm{~m}$ east from the edge of the gully. Soil moisture probes were installed at $1.5 \mathrm{~m}$ downslope of the gully headcut. Six probes were installed at depths of 5,20 and $50 \mathrm{~cm}$ on both banks of the gully and about $15 \mathrm{~cm}$ away from the edge. Two additional probes were placed in the middle of the gully at depths of 5 and $20 \mathrm{~cm}$.

\section{Measuring gully development}

A pin frame (Fig. 2(b)) was designed and built for the measurement of gully profiles of up to $110 \mathrm{~cm}$ width (or wider with additional leg support) with an accuracy of $\pm 0.5 \mathrm{~cm}$. The apparatus consisted of a metal frame with 110 fiberglass rods spaced $1 \mathrm{~cm}$ apart. A metal base platform was constructed and mounted on both sides of the headcut to provide a level baseline for each measurement. The base platform was $1 \mathrm{~m}$ long and had marks every $10 \mathrm{~cm}$. For this study, pin frame measurements were conducted on June 28, July 11, August 6, and August 21 of 2013.

The Water Erosion Prediction Project (WEPP) model (Flanagan and Nearing, 1995) was used to calculate the rainfall excess for each storm event recorded from 28 June to 21 August 2013. A $1 \mathrm{~m} \times 1 \mathrm{~m}$ LIDAR DEM geospatial layer was used to estimate the slope for WEPP modelling of the watershed (KDASC, 2013). The Crete soil type was manually created in WEPP with the attributes acquired from the SSURGO data base (USDA-NRCS, 2005). No-till practice was assumed for crop management. The measurements of rainfall, peak storm intensity and storm 
(a)

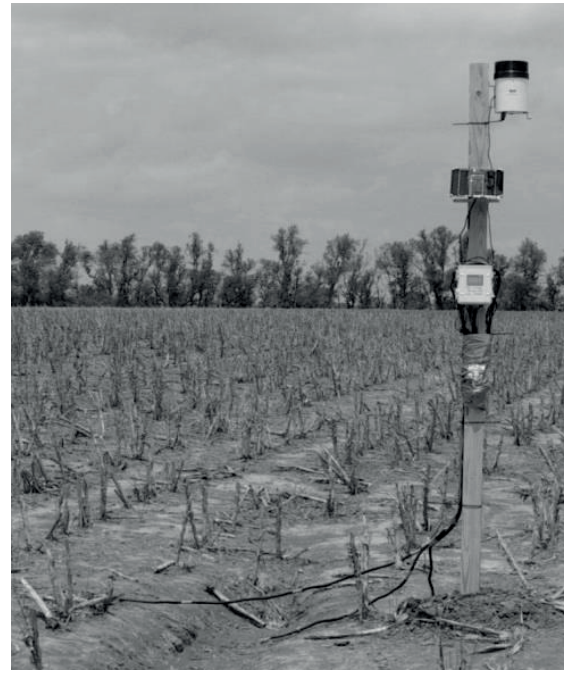

(b)

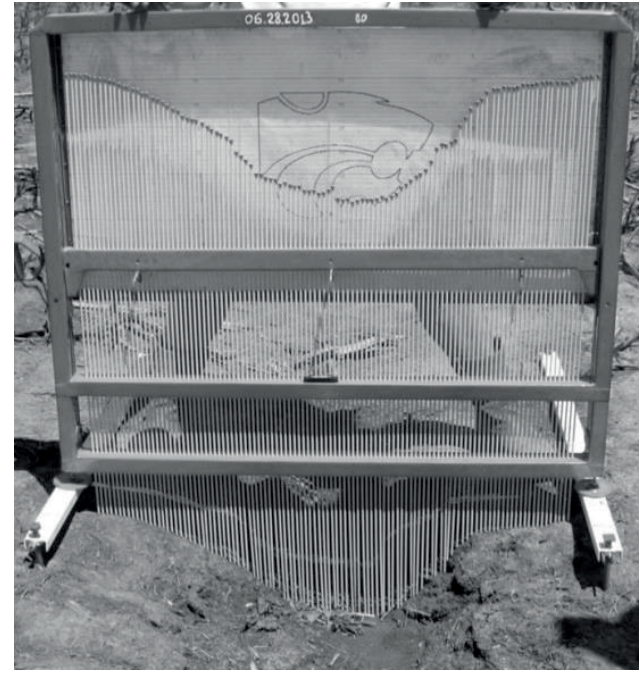

Fig. 2 (a) An equipment set-up installed in the field. (b) A pin frame for measuring the gully profile.

duration were used for model simulations. The soil moisture content was adjusted for each model run according to the readings from the soil moisture probes. An effective volume of runoff and an effective peak of runoff were used from WEPP model output for runoff estimations in this study. Soil loss rates from sheet and rill erosion in the uphill drainage area were estimated with WEPP for each storm event.

\section{RESULTS AND DISCUSSION}

Differences in soil surface elevation in the gully headcut area were evaluated three times after each measurement. The initial and ending three-dimensional profiles of the headcut are presented on the surface plot in Fig. 3. Changes in elevation were detected from about $2 \mathrm{~cm}$ at the sides to almost $15 \mathrm{~cm}$ in the centre of the gully. The longitudinal profile along the centre of the gully shown in Fig. 4(a) was obtained by plotting values of the depth of the 50th pin at 11 pin frame locations 10 $\mathrm{cm}$ apart. The gully cross-sectional profile at $50 \mathrm{~cm}$ downstream of the headcut (middle of the base platform) is presented in Fig. 4(b).

Hydrologic characteristics for all significant rainfall events within the studied period are collected in Table 1. The characteristics include the measured precipitation depth, duration, and peak intensity, the calculated runoff depth and peak intensity, the average soil saturation in the gully profile at the time of 10 min before a storm event, and the results of gully field surveys. Each item in the list represents a rainfall event with data either collected from continuous reading in the field or results of WEPP simulations.

All significant precipitation events were measured during the summer of 2013 and summarized into two major series in Table 1. The first series of events occurred before the

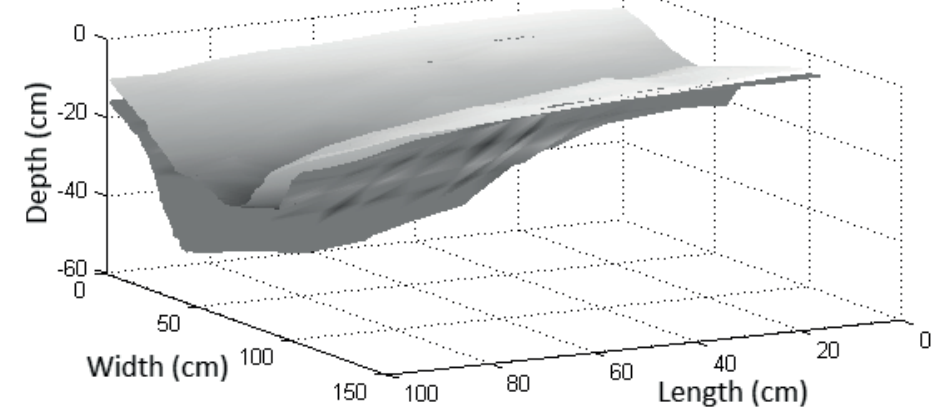

Fig. 3 Three-dimensional profiles of the gully headcut area at the start and end of the study. 
(a)

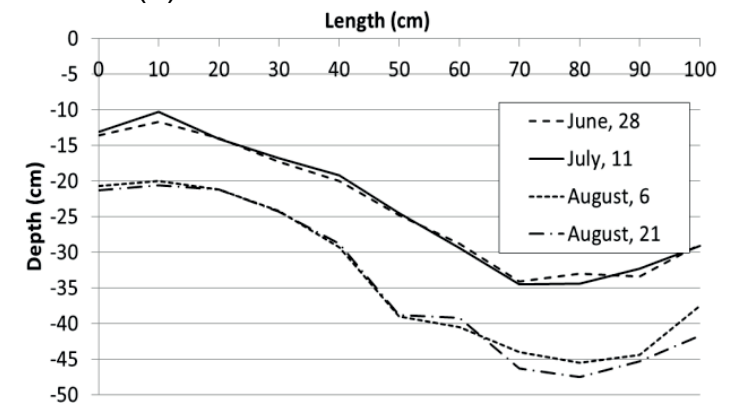

(b)

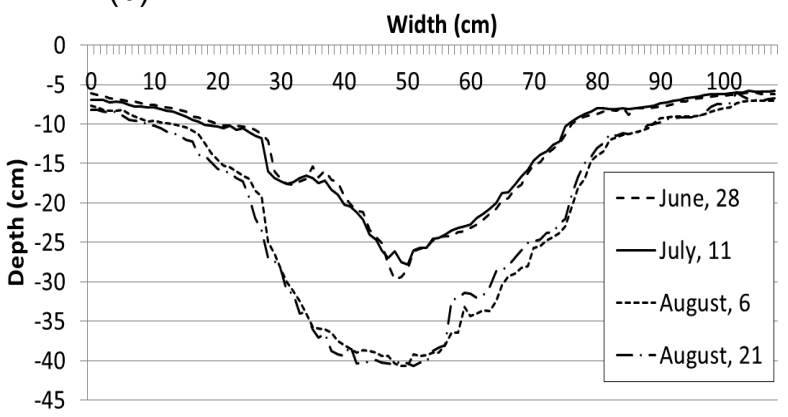

Fig. 4 (a) Ephemeral gully headcut longitudinal profile. (b) Ephemeral gully headcut cross-sectional profile.

Table 1 Hydrologic characteristics for all events during summer of 2013.

\begin{tabular}{|c|c|c|c|c|c|c|c|c|}
\hline \multicolumn{2}{|l|}{ Date } & \multicolumn{3}{|c|}{ Precipitation } & \multirow{2}{*}{$\begin{array}{l}\text { Soil } \\
\text { saturation } \\
(\%)\end{array}$} & \multicolumn{2}{|l|}{ Runoff } & \multirow{2}{*}{$\begin{array}{l}\text { Erosion } \\
\text { detected } \\
\text { yes/no }\end{array}$} \\
\hline Month & Day & $\begin{array}{l}\text { Depth } \\
(\mathrm{mm})\end{array}$ & $\begin{array}{l}\text { Duration } \\
\text { (hr) }\end{array}$ & $\begin{array}{l}\text { Max intensity } \\
(\mathrm{mm} / \mathrm{h})\end{array}$ & & $\begin{array}{l}\text { Amount } \\
(\mathrm{mm})\end{array}$ & $\begin{array}{l}\text { Peak } \\
(\mathrm{mm} / \mathrm{h})\end{array}$ & \\
\hline June & 28 & Survey & & & & & & \\
\hline \multirow[t]{20}{*}{ July } & 9 & 4.45 & 1.72 & 12 & & 0 & 0 & \multirow{20}{*}{ No } \\
\hline & 11 & Survey & & & & & & \\
\hline & 14 & 2.25 & 0.50 & 15 & 84 & 0 & 0 & \\
\hline & 15 & 0.75 & 0.33 & 15 & - & 0 & 0 & \\
\hline & 15 & 9.91 & 0.33 & 120 & 83 & 0 & 0 & \\
\hline & 15 & 0.25 & 0.18 & 1.2 & - & 0 & 0 & \\
\hline & 15 & 6.34 & 0.32 & 106.8 & 85 & 0 & 0 & \\
\hline & 15 & 4.32 & 0.32 & 61.2 & - & 0 & 0 & \\
\hline & 20 & 26.54 & 2.50 & 45.6 & 86 & 9.03 & 8.96 & \\
\hline & 20 & 2.25 & 1.67 & 45.6 & - & 0 & 0 & \\
\hline & 25 & 0.5 & 0.50 & 15 & - & 0 & 0 & \\
\hline & 26 & 54.95 & 4.17 & 243.6 & 87 & 32.33 & 9.05 & \\
\hline & 27 & 0.25 & 0.18 & 0.6 & - & 0 & 0 & \\
\hline & 28 & 0.25 & 0.18 & 0.6 & - & 0 & 0 & \\
\hline & 28 & 11.5 & 5.17 & 6 & 86 & 0 & 0 & \\
\hline & 28 & 2.25 & 1.67 & 6 & - & 0 & 0 & \\
\hline & 29 & 0.5 & 0.50 & 6 & - & 0 & 0 & \\
\hline & 29 & 37.7 & 1.83 & 138 & 95 & 25.44 & 7.88 & \\
\hline & 29 & 34.3 & 1.67 & 228.6 & 95 & 22.22 & 6.64 & \\
\hline & 30 & 2.7 & 0.83 & 15 & - & 0 & 0 & \\
\hline \multirow[t]{14}{*}{ August } & 2 & 40.77 & 1.00 & 228 & 89 & 27.3 & 11.95 & \multirow{13}{*}{ Yes } \\
\hline & 4 & 37.4 & 6.00 & 30.6 & 93 & 18.63 & 3.97 & \\
\hline & 6 & Survey & & & & & & \\
\hline & 7 & 3.54 & 0.35 & 30.6 & - & 0 & 0 & \\
\hline & 8 & 10.75 & 5.17 & 6 & 83 & 0 & 0 & \\
\hline & 8 & 1.5 & 1.83 & 3 & - & 0 & 0 & \\
\hline & 9 & 30.93 & 6.00 & 45.6 & 93 & 14.61 & 6.85 & \\
\hline & 12 & 66.12 & 2.23 & 137.4 & 80 & 49.79 & 19.53 & \\
\hline & 13 & 6.01 & 0.90 & 30.6 & 93 & 0 & 0 & \\
\hline & 13 & 2.25 & 3.33 & 6 & - & 0 & 0 & \\
\hline & 15 & 19.47 & 1.33 & 61.2 & 92 & 5.03 & 7.38 & \\
\hline & 15 & 2.28 & 0.25 & 61.2 & - & 0 & 0 & \\
\hline & 16 & 1.75 & 0.30 & 15 & - & 0 & 0 & \\
\hline & 21 & Survey & & & & & & No \\
\hline
\end{tabular}

surveying date of August 6 and resulted in soil losses in the headcut area of $0.08 \mathrm{~m}^{3}$, or $132 \mathrm{~kg}$, for soil bulk density of $1650 \mathrm{~kg} / \mathrm{m}^{3}$. The second series of events occurred between August 6 and 
August 21, and only very small headcut soil losses of $0.005 \mathrm{~m}^{3}$ were detected. This can be verified by Fig. 4(a) and (b), which shows that major erosion occurred between July 11 and August 6 . In total, 31 events were recorded in the summer of 2013:

- 1 event on July 9 for the period between the surveying dates of June 28 and July 9,

- 20 events for the period between July 9 and August 6, and

- $\quad 10$ events for the last period of surveying dates between August 6 and August 21.

Nine out of 31 events had non-zero runoff depth calculated with WEPP. Four (July 26, July 29

[2 events], August 12) out of those nine events had runoff depth above $20 \mathrm{~mm}$ and precipitation peak intensity greater than $130 \mathrm{~mm} / \mathrm{h}$. All non-zero runoff events, except for the two events on July 29 , can be considered as flashy rainfall events of relatively short duration and high peak intensity. One example of such flashy events is presented for August 12 in the hourly precipitation plot in Fig. 5(b). One may see that the rainfall depth reached its peak in one hour and the event ended after three hours. Soil saturation, also presented in Fig. 5, shows a rapid increase to $97 \%$ during the first two hours followed by the plateau and a decrease after eight hours. No meaningful soil loss was detected during this event.

The events on July 29 differed from the event on August 12, as well as other flashy events, because they represented a different system response. These two short consecutive events of duration of less than two hours had five preceding events on July 27 and July 28 of total duration of $8.6 \mathrm{~h}$. The details of rainfall distribution for this multiple three-day set of events are illustrated in Fig. 5(a). As shown in Fig. 5(a), soil reached its full saturation during the period of initial small events and maintained the saturation condition for almost three days. Total runoff depth and runoff peak intensity were calculated with WEPP for every event in the two series. For a period between July 11 and August 6, the WEPP model estimated the runoff depth of $135 \mathrm{~mm}$ for $276 \mathrm{~mm}$ of rainfall (49\%), while $69 \mathrm{~mm}$ runoff was calculated for $145 \mathrm{~mm}(48 \%)$ of rainfall during the period from August 7 to August 21.
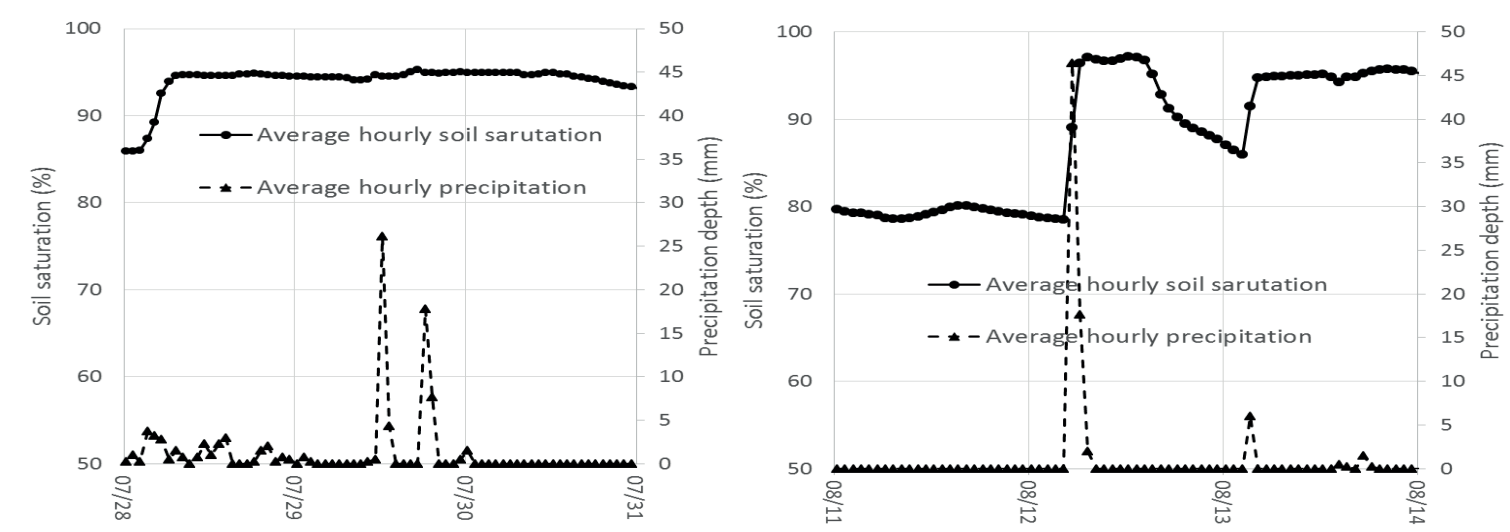

Fig. 5 Soil saturation and precipitation depth during the events on: (a) July 28 and 29; (b) August 12.

One may assume that soil erosion rates would be proportional to runoff depth and/or runoff intensity because of the increased duration and magnitude of shear forces acting on soil particles in a headcut zone due to the inflowing overland water. However, according to the event on August 12 when no change in gully profile was detected, high precipitation and runoff amounts supplemented by high peak runoff rates were not able to cause meaningful soil loss, resulting in the conclusion that erosion rates could be dependent on other factors. One important factor that should be considered is the soil moisture content, and soil saturation condition prior to the runoff event. As exhibited by the events on July 29 and August 12, dry conditions on August 12, as opposed to July 29 events, prevented the headcut from being eroded. Comparing the amount of eroded soil in the headcut area provided by surveying on August $6(132 \mathrm{~kg})$ with WEPP calculated sheet and rill erosion from the uphill drainage area for the events on July $29(122 \mathrm{~kg})$, we conclude that the gully headcut area contributed $52 \%$ of total soil loss at the headcut exit point. This amount is very significant, demonstrating that additional soil loss from headcut to mouth of a gully will increase 
ephemeral gully contribution to total erosion rates from a field. We also note that headcut propagation occurs discretely with time and not every rainfall event can cause it. Thus, combining soil loss from sheet and rill erosion for all summer rainfall events and comparing it with the soil loss from the headcut area, we can say that erosion from headcut area contributed about $25 \%$ of all soil loss from the studied field during the summer of 2013.

\section{CONCLUSIONS}

This study examined the impacts of precipitation and runoff on the development of an ephemeral gully. The results show that high runoff intensity and the associated runoff and precipitation depths were not the only factors in headcut development. Headcut progression rates increased dramatically when antecedent soil moisture levels were elevated prior to a rainfall event. Other factors, such as runoff depth, duration, and frequency, can be influential in gully development and need to be taken into consideration for accurate estimation of soil losses.

Acknowledgements This material is based on work supported by the USDA National Institute of Food and Agriculture (NIFA) under Agreement No. 2011-51130-31128. The authors thank Dr Gerard Kluitenberg for discussions and valuable comments regarding ephemeral gully formation processes and Mr Jonathan Zeller for assistance with designing and building the pin-frame.

\section{REFERENCES}

Alonso, C.V., et al. (2002) Predicting head cut erosion and migration in concentrated flows typical of upland areas. Water Resources Research 38(12), 39-1-39-15.

Bennett, S.J., et al. (2000) Characteristics of actively eroding ephemeral gullies in an experimental channel. Trans. American Society of Agricultural Engineers 43(3) 641-649.

Capra, A., Porto, P. and Scicolone, B. (2009) Relationships between rainfall characteristics and ephemeral gully erosion in a cultivated catchment in Sicily (Italy). Soil \& Tillage Research 105, 77-87.

Casalí, J., Giménez, R. and Bennett, S. (2009) Gully erosion processes: monitoring and modelling. Earth Surface Processes and Landforms 34(14), 1839-1840.

Castillo, C., et al. (2012) Comparing the accuracy of several field methods for measuring gully erosion. Soil Science Society of America Journal 76(4), 1319-1332.

Decagon. (2013) Decagon Devices Inc., Pullman, WA, USA. Available from http://www.decagon.com/.

Di Stefano, C. and Ferro, V. (2011) Measurements of rill and gully erosion in Sicily. Hydrological Processes 25, 2221-2227.

Flanagan, D.C. and Nearing, M.A. (1995) USDA-Water Erosion Prediction Project: Hillslope profile and watershed model documentation. NSERL Report No.10.

Gong, J.G., et al. (2011) An experimental study on dynamic processes of ephemeral gully erosion in loess landscapes. Geomorphology 125, 203-213.

KDASC (2013) Kansas Data Access and Support Center, Topeka, Kan., USA. Available from http://www.kansasgis.org/.

Morgan, R.P.C., et al. (1998) The European Soil Erosion Model (EUROSEM): A dynamic approach for predicting sediment transport from fields and small catchments. Earth Surface Processes and Landforms 23(6) 527-544.

Nachtergaele, J.P., et al. (2001) The value of a physically based model versus an empirical approach in the prediction of ephemeral gully erosion for loess-derived soils. Geomorphology 40(3) 237-252.

Onset (2013) Onset HOBO Dataloggers. Bourne, Massachusetts, USA. Available from http://www.onsetcomp.com/.

Poesen, J., et al. (2003) Gully erosion and environmental change: importance and research needs. Catena 50, 91-133.

Robinson, K.M. and Hanson, G.J. (1996) Gully headcut advance. Trans. American Society of Agricultural Engineers 39, 33-38.

Stein, O.R. and Julien, P Y. (1993) Criterion delineating the mode of headcut migration. Journal of Hydraulic Engineering 119, 37-50.

Taguas, E.V., et al. (2012) Modeling the contribution of ephemeral gully erosion under different soil managements: a case study in an olive orchard microcatchment using the AnnAGNPS Model. Catena 98, 1-16.

Thomas, A.W. and Welch, R. (1988) Measurement of Ephemeral Gully Erosion. Transactions of the American Society of Agricultural Engineers 31, no. 6: 1723-1728.

Thorne, C.R., Grissinger, E.H. and Murphey, J.B. (1984) Field study of ephemeral cropland gullies in northern Mississippi. New Orleans, LA, USA ed. St. Joseph, MI, USA: ASAE, .

USDA-NRCS. (2005) Soil Survey Geographic (SSURGO) Database. USDA Natural Resources Conservation Service, Washington, D.C. Available from http://soildatamart.nrcs.usda.gov/default.aspx.

Valentin, C., Poesen, J. and Yong Li. (2005) Gully erosion: impacts, factors and control. Catena 63(2-3), 132-153.

Wells, R., Bennett, S. and Alonso, C. (2009) Effect of soil texture, tailwater height, and pore-water pressure on the morphodynamics of migrating headcuts in upland concentrated flows. Earth Surface Processes and Landforms 34(14), $1867-1877$.

Wells, R., et al. (2013) An empirical investigation of gully widening rates in upland concentrated flows. Catena 101, 114-121.

Wilson, G.V., Cullum, R.F. and Römkens, M.J.M. (2008) Ephemeral gully erosion by preferential flow through a discontinuous soil-pipe. Catena 73, 98-106.

Zhang, Yongguang, et al. (2007) Characteristics and factors controlling the development of ephemeral gullies in cultivated catchments of Black Soil Region, Northeast China. Soil \& Tillage Research 96, 28-41. 